\title{
Charles Darwin's On the Origin of Species
}

\author{
Michael Ruse
}

Published online: 23 February 2007

(C) Springer Science+Business Media B.V. 2007

Mr Charles Darwin, well known to us all as the author of the delightful travel book Journal of Researches into the Geology and Natural History of the Various Countries Visited by HMS Beagle (1839) (better known as The Voyage of the Beagle), has now produced an audacious work that will surely be the topic of much conversation for months if not years to come. In his newly published book, On the Origin of Species by Means of Natural Selection or the Preservation of the Favoured Races in the Struggle for Existence, to give it the full title, Mr Darwin openly declares himself a Vestiginarian! Like the unknown author of the Vestiges of the Natural History of Creation (1844), Mr Darwin has embraced transmutationism, what $\mathrm{Mr}$ Herbert Spencer calls "evolution," and what Mr Darwin himself calls "descent with modification." In his new book-to which we will give the abbreviated title of the Origin-Mr Darwin openly declares that all living creatures (quick and dead) are the end results of a long process of natural development from (as he says) "one or a few forms." And although his book says little about our own species, he makes very clear at the end that we too are part of the picture. "Light will be thrown on the origin of man and of his history." Yes, indeed!

So would open a review of the Origin written shortly after the book appeared in 1859. I am writing in 2006, close to the 150th anniversary of the publication, and (declaring an interest) I should tell you that I have just signed a contract with Cambridge University Press to

M. Ruse (凹)

Department of Philosophy, Florida State University,

Tallahassee, FL 32306, USA

e-mail:mruse@mailer.fsu.edu co-edit (with the distinguished historian Robert J. Richards) a Companion to the Origin. So I take it without argument that as a historical work the Origin is of great significance. Goodness, the portrait of Darwin has even replaced Charles Dickens on the back of the English ten pound note, although rumor has it that the real reason for the shift is that Darwin had a fuller beard than Dickens and thus was less easy to forge! My mandate here is to assess the Origin from today's perspective, considering its contemporary value as a work of scholarship, and in respects this is a lot less easy to do than from the perspective of say 1860 . It would be all too easy simply to dismiss it as something irretrievably dated and to leave matters at that. Frankly, I would be worried if one could not dismiss it as dated, for that would suggest that Darwin's ideas have so little interest or value that no one has bothered to try to critique them or to take the discussion further. So remember that here I am not so much suspending critical evaluation, as looking at what proved interesting and stimulating in the Origin, rather than ways to take cheap shots at the past from the present. ${ }^{1}$

\footnotetext{
${ }^{1}$ I do not want to spend the whole of this review referencing myself. So here let me say that four of my books that deal with Darwin and his revolution are The Darwinian Revolution: Science Red in Tooth and Claw [1999 (1979)], Monad to Man: The Concept of Progress in Evolutionary Biology (1996), Mystery of Mysteries: Is Evolution a Social Construction? (1999), and Darwin and Design: Does Evolution have a Purpose? (2003). Two books that look at the science in Darwin and compare it to the present are Darwinism and its Discontents (2006) and Charles Darwin (2007). Two books dealing with evolution and religion are Can a Darwinian be a Christian? The Relationship between Science and Religion (2001) and The Evolution-Creation Struggle (2005). A book which looks at Freud on homosexuality was Homosexuality: A Philosophical Analysis (1988).
} 
Let us turn to the content of Darwin's book, but as we do so, let us keep in mind something as important today as it was yesterday. Although, when he published the Origin, Darwin had been stricken for 20 years with ongoing ill health, he had nevertheless pushed himself to the very first rank of British scientists. His detailed geological studies, based on his 5-year-long circumnavigation of the world in HMS Beagle under the captaincy of Robert Fitzroy, were models of empirical inquiry. His massive detailed studies of barnacles, both living and fossil, were exemplary instances of careful and thoughtful study of the world of life. We may or may not agree with Darwin's reasoning. We must respect it and cannot ignore it. Today no less than yesterday we feel at once that we are in the hands of a master. This is not some outsider trying his hand. This is a real professional at work. We can add also that whether or not we agree with Darwin, his warm and easy style makes it exceptionally easy to follow his thinking. Few will come away confused as to the points that he is making. The charming writing of the Voyage of the Beagle is once again in evidence. Some may complain-in fact in 1860 his bitter rival the anatomist Richard Owen, writing in the Quarterly Review, did complain-that the style is too easy for a serious work of science. With this I can only disagree. Too often specialists feel that, save their writing is opaque and cumbersome, they are not being serious and profound. I am not saying that (in his style) Darwin has the brilliance of Richard Dawkins in the Selfish Gene (1976). But he is very good. Would that German metaphysicians and French deconstructivists took lessons from him.

Darwin begins by taking the reader into the world of the breeder-the farmer who wants fatter pigs and hairier sheep, the enthusiast who wants ever more fanciful feathers on his pigeon-and he argues that this is a model for change in nature. Here, as throughout his book, Darwin is riding two horses and it is not always clear which back is mounted at any one time. From the one saddle, Darwin thinks that the changes brought about by the breeders are enough to support the changes he supposes through nature. We confess we are not convinced of this. Who ever changes a horse into a cow? From the other saddle, Darwin prepares the way for his mechanism of change by showing how selection of the desired is the way that breeders bring about the changes that they effect. This is surely true, although whether selection by breeders is truly analogous to what Darwin calls "natural selection" is indeed the big question at issue. Judging from today, general opinion would be that Darwin was just scratching at the surface but that he was scratching at the right surface. We now have massive evidence of the power of selection in artificial and semi- artificial circumstances, and can change organisms so much that they are really new species, isolated from all others. It is true that we have never changed a horse into a cow, but then neither did nature. They spring from common stock.

Moving to his main mechanism, Darwin first makes reference to the deductions of the Reverend Robert Malthus [1914 (1826)], who showed how readily population numbers outstrip supplies of food and space. Here Darwin's genius glows as brightly today as it ever did. With reason, the calculations of Malthus were generally taken to show the impossibility of major change. If you feed the poor from state funds in one generation, you only have more of them in the next. There is bound to be a struggle for existence, save only people practice prudential restraint. Darwin takes the struggle as force that brings on unlimited change, for in the world of animals and plants there can be no prudential restraint, and so in the bloody battle for survival those with advantageous features will tend to succeed. Let us quote Darwin on this.

Let it be borne in mind in what an endless number of strange peculiarities our domestic productions, and, in a lesser degree, those under nature, vary; and how strong the hereditary tendency is. Under domestication, it may be truly said that the whole organisation becomes in some degree plastic. Let it be borne in mind how infinitely complex and close-fitting are the mutual relations of all organic beings to each other and to their physical conditions of life. Can it, then, be thought improbable, seeing that variations useful to man have undoubtedly occurred, that other variations useful in some way to each being in the great and complex battle of life, should sometimes occur in the course of thousands of generations? If such do occur, can we doubt (remembering that many more individuals are born than can possibly survive) that individuals having any advantage, however slight, over others, would have the best chance of surviving and of procreating their kind? On the other hand, we may feel sure that any variation in the least degree injurious would be rigidly destroyed. This preservation of favourable variations and the rejection of injurious variations, I call Natural Selection (Darwin 1859, pp 80-81).

(Note that he does not use the alternative phrase, survival of the fittest. This was a phrase coined by Spencer, and Darwin only added it to later editions of the Origin at the urging of Alfred Russel Wallace, the co-discoverer of natural selection.) 
Darwin has many most interesting things to say about natural selection, a process that he argues leads to the wonderful display of fossils in the geological record as well as the multitudinous animals and plants living today. It is still amusing that Darwin appropriates a Christian metaphor when he speaks of history as a "Tree of Life," with us all today at the outer tips of the branches. It is worth also noting in passing that Darwin's mechanism of natural selection shows roots in the Christian faith. It leads to adaptations or contrivances like the hand and the eye. In other words, it supposes that nature is not thrown together randomly but is organized and it works. In the language of the philosophers, the eye shows final cause in seeing and the hand shows final cause in grasping. Here Darwin shows the effects of his training and reading. Passages of the Origin would not be out of place in Archdeacon Paley's Natural Theology [1819 (1802)] or one of the celebrated Bridgewater Treatises (Gillespie 1950). Darwin would never agree with today's neo-Creationists, the Intelligent Design Theorists, that we need interventions from outside the course of nature to explain the adaptive complexity of organisms, but he does agree with them that adaptation is the chief feature of organic life.

Natural selection leading to adaptation is of course the first of Darwin's big contributions to evolutionary theory. Paradoxically, writing today in 2006 we are more inclined to give him credit than his contemporaries in 1859. Today, although there are still doubters about the ubiquity of natural selection-for instance, the late Stephen Jay Gould (2002) - general opinion among professional evolutionists is that Darwin got it right. The chief feature of the organic world is its adaptive or organized complexity [as the late John Maynard Smith (1969) used to call it] and natural selection is the only mechanism that speaks to this. (Darwin's secondary mechanism of sexual selection is also involved, although some simply subsume it beneath natural selection.) Darwin in the Origin does not offer much direct evidence and today again this is a place where time has moved on. We now have massive evidence of the workings of selection in nature. Very well known are the studies done in the 1950s by H.B.D. Kettlewell (1973) on industrial melanism in butterflies, and the studies for the past 30 years by Peter (1986) and Rosemary Grant (1989) in the Galapagos Archipelago on Darwin's Finches. But they are just the tip of a huge iceberg. Of great practical importance is the fact that there has never been a medicine introduced that did not become ineffective in its original state because the rapid selection fueled evolution of the attacking microorganisms.
The second part of the Origin, by far the bigger section, is Darwin's second great contribution to evolutionary theory, and it too is as significant today as it ever was. This part is given to a review of biological discussions in different fields in the light of the mechanism of natural selection. The approach taken here, namely using descent through natural selection to explain phenomena and in turn using the explanations to support descent through natural selection, is not Darwin's own invention. It is the method of scientific argumentation championed by William Whewell in his Philosophy of the Inductive Sciences (1840). Whewell referred to this as a "Consilience of Inductions." Just like Newton before him and the geologists establishing plate tectonics after him, Darwin did a terrific and still powerful job of promoting a consilience. Paradoxically and rather sadly, Whewell was so opposed to what he thought were the irreligious aspects of Darwin's theory that, in his position of Master of Trinity College Cambridge, he refused to allow the Origin on the college library's shelves.

With superb confidence, which time has only burnished, Darwin takes us through the branches of his subject-instinct, paleontology, the geographical distributions of organisms on the globe, classification, morphology, embryology, and much, much more. It is hard to pick out one topic rather than another, but geography deserves special praise. Why, Darwin asks, are the inhabitants of islands off the coast of Africa similar although not identical to the inhabitants of Africa? Why are they not like the inhabitants of South America? Why conversely are the inhabitants of islands off the coast of South American-including the well-known Galapagos Archipelago-like the inhabitants of South America and not like the inhabitants of Africa? Can there be any explanation except descent with modification?

The most striking and important fact for us in regard to the inhabitants of islands, is their affinity to those of the nearest mainland, without being actually the same species. Numerous instances could be given of this fact. I will give only one, that of the Galapagos Archipelago, situated under the equator, between 500 and 600 miles from the shores of South America. Here almost every product of the land and water bears the unmistakeable stamp of the American continent. There are twenty-six land birds, and twenty-five of those are ranked by $\mathrm{Mr}$ Gould as distinct species, supposed to have been created here; yet the close affinity of most of these birds to American species in every character, in their 
habits, gestures, and tones of voice, was manifest. So it is with the other animals, and with nearly all the plants, as shown by Dr. Hooker in his admirable memoir on the Flora of this archipelago. The naturalist, looking at the inhabitants of these volcanic islands in the Pacific, distant several hundred miles from the continent, yet feels that he is standing on American land. Why should this be so? Why should the species which are supposed to have been created in the Galapagos Archipelago, and nowhere else, bear so plain a stamp of affinity to those created in America? There is nothing in the conditions of life, in the geological nature of the islands, in their height or climate, or in the proportions in which the several classes are associated together, which resembles closely the conditions of the South American coast: in fact there is a considerable dissimilarity in all these respects. On the other hand, there is a considerable degree of resemblance in the volcanic nature of the soil, in climate, height, and size of the islands, between the Galapagos and Cape de Verde Archipelagos: but what an entire and absolute difference in their inhabitants! The inhabitants of the Cape de Verde Islands are related to those of Africa, like those of the Galapagos to America. I believe this grand fact can receive no sort of explanation on the ordinary view of independent creation; whereas on the view here maintained, it is obvious that the Galapagos Islands would be likely to receive colonists, whether by occasional means of transport or by formerly continuous land, from America; and the Cape de Verde Islands from Africa; and that such colonists would be liable to modifications; the principle of inheritance still betraying their original birthplace (pp 397-398).

This explanation is as vital and good today as it was in 1859.

Again, to take a topic much discussed in 1859 by the anatomists and still discussed today by anatomists, why do the forelimbs of animals show similarities-what Richard Owen (1848) called homologies-when they are used for different ends? "What can be more curious than that the hand of a man, formed for grasping, that of a mole for digging, the leg of the horse, the paddle of the porpoise, and the wing of the bat, should all be constructed on the same pattern, and should include the same bones, in the same relative positions?" Replies Darwin: "The explanation is manifest on the theory of the natural selection of successive slight modifications, each modification being profitable in some way to the modified form, but often affecting by correlation of growth other parts of the organisation. In changes of this nature, there will be little or no tendency to modify the original pattern, or to transpose parts."

There is more, much more, that we could mention. But the time has now come to turn to discussion. Darwin established beyond reasonable doubt, as they say in courts of law, that descent with modification accounts for the history of life and the spread of organisms we find today. There is no other way, naturally, to account for the facts that Darwin brings to our attention. On the evidence offered in the Origin, there is less of a case for the mechanism natural selection. As has been noted above, time has remedied that omission and today selection rules supreme. What we do not get from the Origin (and this was noted by the reviewers of the day) is really helpful information on how features are transmitted from one generation to another and what causes new features. Darwin discusses these issues at length but is more anecdotal than persuasive. As we now know in 2006, in the twentieth century the true principles of heredity-going back to the work of the Moravian monk Gregor Mendel living at the same time as Darwin - have been uncovered and developed. We now have a full theory of genetics and it is the backbone of modern evolutionary theory-a backbone supporting the full force of Darwinian selection.

In fairness I should say that there are those who think that some of the advances in the areas of biology explained by selection-paleontology, embryology, and so forth-require new principles that make selection ineffective and perhaps even misleading. Stephen Jay Gould was a big one for arguing in this way, proposing his theory of punctuated equilibrium (where evolution proceeds in jumps or starts) as an alternative to Darwinian selection (Eldredge and Gould 1972). Unfortunately, neither Gould nor any of the other critics have been able to provide an adequate alternative theory of heredity to explain something like punctuated equilibrium. Mendelism (including its molecular successor) has no place for such jumps or starts (Stebbins and Ayala 1981). Recently, it is the students of embryology, now known as evolutionary development, or evo-devo, who have been trying to break the Darwinian ties. Three leading proponents, referring to some incredible homologies that have now been found down at the molecular level-the developmental genes of the fruitfly and the human are practically identical—write:

The homologies of process within morphogenetic fields provide some of the best evidence for 
evolution-just as skeletal and organ homologies did earlier. Thus, the evidence for evolution is better than ever. The role of natural selection in evolution, however, is seen to play less an important role. It is merely a filter for unsuccessful morphologies generated by development. Population genetics is destined to change if it is not to become as irrelevant to evolution as Newtonian mechanics is to contemporary physics (Gilbert et al. 1996, p 368).

As with punctuated equilibrium these are fears or claims that are exaggerated. It now seems that organisms are not built on new principles each time. They are more like Lego creations, where the same pieces are used again and again to make very different end results. Why this should be a worry for Darwin or a challenge for natural selection entirely escapes me.

Finally, let us ask the question that (in America particularly) is as much at the fore of the minds of people today as it was at the fore of the minds of Darwin's contemporaries. How far can one go with Darwin if one is a practicing, believing Christian? If one believes that Jesus was God Incarnate, who died on the Cross for our sins, and makes possible our eternal salvation, can one accept descent with modification? My answer today is that which most people, including most practicing Christians (excluding the American South) gave back then. It is many years now since either scientists or the layman felt constrained by literal readings of Genesis. No one believes in the date set by Archbishop Ussher, that the world is but 6,000 years old. More positively, remember how Darwin's mechanism of natural selection speaks directly to the significance of design, of final cause. If evolution be true, there is no reason why God should not have created through law rather than miracle. After all, would we say that the Briton who builds a power loom to make his cloth is less worthy as a man than the one who persists in using a hand loom?

Christians in the past and Christians today have reservations about Homo sapiens. Darwin clearly wants to include us in the picture, and as far as our mortal frame is concerned, there can be no objection. But as creatures made in the image of God, as beings with immortal souls, many believers will balk. They will call for divine intervention. And perhaps at this point Darwin and his followers can lean back and give Christians their case. A soul may be real-more real than most-yet not a proper object of scientific investigation. I am not saying that one must believe in souls-Darwin did not and neither do I-but I am saying that if Christians want to believe in souls, who is to deny them that pleasure.

How does one judge the Origin overall from 2006? I find a comparison with Freud very enlightening. (A comparison with Marx may make the same point.) I have read a great deal of Freud's writings very carefully. I do not think of myself as a Freud expert as (immodestly) I would think of myself as a Darwin expert, but I think I can talk knowledgeably about his ideas. Some, if not just about all, of Freud's writings I find very exciting. He like Darwin can write in a terrific way and make his ideas understandable and compelling at the moment. I recognize fully that Freud has been very influential. Has he been more influential than Darwin? I don't know and don't much care. They have both been very influential, and not just in their own fields but in culture generally. There are many ideas in Freud that I think are absolutely spot on-much more so than the ideas of some of his followers. For instance, it seems to me to be absolutely the case that homosexual males tend to have close relationships with mother and difficult relationships with father. Not all homosexuals, not all mothers, not all fathers, but many-more so than with heterosexual males [Freud 1955 (1905)].

Yet when all is said and done I just don't think that Freud got it. I just don't think that he had a basic theory of human nature that works or that is true of the empirical world. Insights but not truth. In the case of homosexual males, Freud argues that it is the dysfunctional triangle that brings on the orientation. You cannot successfully resolve the Oedipus tensions because you want to have sex with mother, you know you can't, and so you revert to a childhood state of being attracted to males, and the tension is resolved. That seems to me just plain wrong. Freud got it backwards. Boys are born with their orientations and it is they who elicit the behavior rather than the parents who impose it. A gay son in the making wants to play with mum a lot more than with dad, and so the attitudes evolve and harden. There was no chap called Oedipus, it was not engrained in human nature by Lamarckian (inheritance of acquired characteristics) processes, and I very much doubt that most male homosexuals really want to romp between the sheets with their mothers.

Darwin is different. You can criticize as much as you like. He did get things wrong and he did offer too little evidence too often. But ultimately he was right. $\mathrm{He}$ grasped the truth about the way that the world is. It is as simple as that. Evolution is true and natural selection is its mechanism. No more but certainly no less. So let us end by going back to the Origin and to its final words. We are given a paragraph of poetry in prose, somewhat ironically modified from a review Darwin 
read in 1838, by the Scottish physicist David Brewster, on a work of positivism by August Comte. You will not be surprised to learn that Brewster was praising God. The naturalist Charles Darwin praises evolution.

It is interesting to contemplate an entangled bank, clothed with many plants of many kinds, with birds singing on the bushes, with various insects flitting about, and with worms crawling through the damp earth, and to reflect that these elaborately constructed forms, so different from each other, and dependent on each other in so complex a manner, have all been produced by laws acting around us. These laws, taken in the largest sense, being Growth with Reproduction; inheritance which is almost implied by reproduction; Variability from the indirect and direct action of the external conditions of life, and from use and disuse; a Ratio of Increase so high as to lead to a Struggle for Life, and as a consequence to Natural Selection, entailing Divergence of Character and the Extinction of less-improved forms. Thus, from the war of nature, from famine and death, the most exalted object which we are capable of conceiving, namely, the production of the higher animals, directly follows. There is grandeur in this view of life, with its several powers, having been originally breathed into a few forms or into one; and that, whilst this planet has gone cycling on according to the fixed law of gravity, from so simple a beginning endless forms most beautiful and most wonderful have been, and are being, evolved (pp 489-490).

\section{Envoi}

Even a friendly critic might complain that the Origin is too circumscribed with respect to the broader implications of the theory of evolution through natural selection. Was it enough for Charles Darwin simply to acknowledge that his theory has things of interest and importance to say about the human species and then leave things at that? Surely, Darwin should have explored these matters in some detail? After all, others were quick to do so, from Darwin's great supporter Thomas Henry Huxley in his Man's Place in Nature (1863) down to philosopher Dan Dennett's recent book, Breaking the Spell: Religion as a Natural Phenomenon (2006). Did Darwin not owe us some discussion about whether evolution-natural selection even-has full application to the human species? What about culture? Surely Darwin should have told us whether he thought humans are like animals and basically powered by biology alone, or if we have escaped our animal heritage and live purely in a world of (human-constructed) culture?

With hindsight, we can exonerate Darwin, even if we do not agree with all of his ideas. On the negative side (if such it be), Darwin deliberately excluded humans from the main discussion of the Origin (although note that he does include us when he is discussing such things as vertebrate homologies). His aim in the Origin was to get the basic ideas of his theory out on the table. He knew full well that as soon as he published, the "monkey question" would be on everybody's mind, and so he was making sure that his central thinking would not get lost in the rush. In this, he was very successful. Virtually every review of the day brought up the human question, but every review of the day first gave detailed coverage of the main points of the theory. That was a crucial point. No one thought the Origin was simply special pleading about humankind. It made it a great deal easier for people, including (especially including) religious people, to accept evolution. They could even accept evolution for humans-although they usually wanted miracles for immortal souls-because the real case was being made for non-humans. Accept it for dogs and cats, for oak trees and elm trees, and it was a lot easier to agree that we humans really cannot stand alone.

Second, on the positive side, 12 years later Darwin did broach the human question fully in his Descent of Man (1871). He was not a paleoanthropologist (student of the history of humankind) and so much of the empirical matter came from others, but Darwin made it very clear that he did think that we humans come fully under the evolutionary umbrella. In respects, he is not always that tuned to the questions that we now find fascinating. I am never quite sure whether Darwin thinks that humans are biologically determined or greatly controlled by selection [as one finds in the writings of someone like the sociobiologist Edward O. Wilson, author of On Human Nature (1978)], or whether he thinks that culture is now autonomous [as is argued by many philosophers, recently by David Buller in his Adapting Minds (2005)]. Probably a bit of both, with an inclination to the biology.

In other respects, the discussion today picks up with the Descent. Darwin spends considerable time discussing the nature of morality and its roots in selection, trying to puzzle out how something that starts in a struggle of one against the other can nevertheless generate a sense of duty of one to others. His solution in part invokes what we today call "reciprocal altruism," namely you be nice to me and I will be nice to 
you. In part, it invokes what today we call "group selection," where Darwin thought that help given within the population gives maximum protection from threats from without the population. Here he stands in line with the authors of Unto Others: The Evolution of Altruism (1997), biologist David Sloan Wilson and philosopher Elliott Sober. Darwin's discussion of religion, although brief, is even more up-to-date, as he provides a naturalistic account of its origins, arguing that it is rooted in the animal tendency to see intelligence even when none exists. He is not contemptuous of religion, as is Dennett, and explicitly he argues (in direct opposition to E.O. Wilson) that a naturalistic account of origins in itself can tell us nothing of truth or falsity of content, but he anticipates people like cultural theorist Pascal Boyer [Religion Explained (2002)] and anthropologist Scott Atran [In Gods We Trust (2004)] in seeing religion as something that is basically a side-effect of selection for useful characteristics-looking for intelligent agents being of prime importance for organisms who are either predator or prey or both.

I do not want to make too much of all of this, but I am sure that today Charles Darwin would be entering vigorously not only into scientific implications, revisions, and extensions of his theory, but also into the broader issues, especially centering on that ever-fascinating organism, H. sapiens ${ }^{2}$.

\section{References}

Atran S (2004) In Gods we trust: the evolutionary landscape of religion. Oxford University Press, New York

Boyer P (2002) Religion explained: the evolutionary origins of religious thought. Basic Books, New York

Brewster D (1838) Review of Comte's 'Cours de Philosophie Positive'. Edinburgh Rev 67:271-308

Buller D (2005) Adapting minds: evolutionary psychology and the persistent quest for human nature. MIT, Cambridge

Chambers R (1844) Vestiges of the natural history of creation. Churchill, London

Darwin C (1839) Journal of researches into the geology and natural history of the various countries visited by HMS Beagle. Henry Colburn, London

Darwin C (1859) On the origin of species. John Murray, London

Darwin C (1871) The descent of man. John Murray, London

Dawkins R (1976) The selfish gene. Oxford University Press, Oxford

Dennett DC (2006) Breaking the spell: religion as a natural phenomenon. Viking, New York
Eldredge N, Gould SJ (1972) Punctuated equilibria: an alternative to phyletic gradualism. In: Schopf TJM (ed) Models in paleobiology. Freeman, Cooper, San Francisco, pp 82-115

Freud S [1955 (1905)] Three essays on the theory of sexuality. In: The standard edition of the complete psychological works of Sigmund Freud, vol 7. Hogarth, London, pp 125-243

Gilbert SF, Opitz JM, Raff RA (1996) Resynthesizing evolutionary and developmental biology. Dev Biol 173:357-372

Gillespie CC (1950) Genesis and geology. Harvard University Press, Cambridge

Gould SJ (2002) The structure of evolutionary theory. Harvard University Press, Cambridge

Grant PR (1986) Ecology and evolution of Darwin's finches. Princeton University Press, Princeton

Grant RB, Grant PR (1989) Evolutionary dynamics of a natural population: the large cactus finch of the Galapagos. University of Chicago Press, Chicago

Huxley TH (1863) Evidence as to man's place in nature. Williams and Norgate, London

Kettlewell HBD (1973) The evolution of melanism. Clarendon, Oxford

Malthus TR [1914 (1826)] An essay on the principle of population, 6th edn. Everyman, London

Maynard Smith J (1969) The status of neo-Darwinism. In: Waddington $\mathrm{CH}$ (ed) Towards a theoretical biology. Edinburgh University Press, Edinburgh

Owen R (1848) On the archetype and homologies of the vertebrate skeleton. Voorst, London

Owen R (1860) Darwin on the origin of species. Edinburgh Rev 111:487-532

Paley W [1819 (1802)] Natural theology (collected works: IV). Rivington, London

Ruse M [1999 (1979)] The Darwinian revolution: science red in tooth and claw, 2nd edn. University of Chicago Press, Chicago

Ruse M (1988) Homosexuality: a philosophical inquiry. Blackwell, Oxford

Ruse M (1996) Monad to man: the concept of progress in evolutionary biology. Harvard University Press, Cambridge

Ruse M (1999) Mystery of mysteries: is evolution a social construction? Harvard University Press, Cambridge

Ruse M (2001) Can a Darwinian be a Christian? The relationship between science and religion. Cambridge University Press, Cambridge

Ruse M (2003) Darwin and design: does evolution have a purpose? Harvard University Press, Cambridge

Ruse M (2005) The evolution-creation struggle. Harvard University Press, Cambridge

Ruse M (2006) Darwinism and its discontents. Cambridge University Press, Cambridge

Ruse M (2007) Charles Darwin. Blackwell, Oxford

Sober E, Wilson DS (1997) Unto others: the evolution of altruism. Harvard University Press, Cambridge

Stebbins GL, Ayala FJ (1981) Is a new evolutionary synthesis necessary? Science 213:967-971

Whewell W (1840) The philosophy of the inductive sciences, 2 vols. Parker, London

Wilson EO (1978) On human nature. Cambridge University Press, Cambridge

\footnotetext{
2 These and related topics are the subjects of discussion in my new book Charles Darwin (2007).
} 